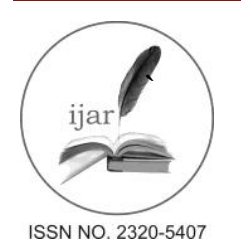

Journal homepage:http://www.journalijar.com
Journal DOI:10.21474/IJAR01

RESEARCH ARTICLE

\title{
GENETIC DIVERSITY IN LARGE CARDAMOM (Amomum subulatum Roxb.)DISSECTED USING RAPD
} MARKERS.

\author{
Raju Chaudhary, Surya Kant Ghimire, Bal Krishna Joshi, Bishnu Raj Ojha, Raj Kumar Niroulaand Pradip \\ Kumar Yadav.
}

\section{Manuscript Info}

Manuscript History:

Received: 12 April 2016

Final Accepted: 19 May 2016

Published Online: June 2016

Key words:

Nepal Cardamom, Cultivars, variation, genetic distance, cluster

*Corresponding Author

Raju Chaudhary.

\begin{abstract}
Large cardamomis major cash generating spice having high commercial impact on farmers forits high economical values, beside spice it is used for medicinal purposes. Present study was done to explore genetic variation present in Nepal cardamom (Amomum subulatum Roxb.)socollections of large cardamom were done from three districts of Eastern hills of Nepal during 2012. Presence of wild cardamom in forests of Nepal made possibility of high genetic diversity of large cardamoms found in Nepal. All together 16 samples were analyzed using 25 random primers that generated 169 different loci and were found highly polymorphic (90.90\%).The Nei'sgenetic diversity among all collected accessions was found to be 0.295 similarly; Shannon Information Index value of 0.448 also suggested high genetic diversity for collected large cardamom accessions. Dendrogram based on Dice coefficient separates all the cultivars into 4 major clusters at 0.68 level.Wild relatives of large cardamom formed separate cluster similarly cultivar Varlange also formed separate cluster depicts large variation in these cultivars in respects to cultivated cultivars viz. Ramsay, Golsay, Ramla, Chivesay and Jirmale. This result shows the potentiality of RAPD markers in accessing genetic diversity in clonally propagated crop such as large cardamom and also to distinguish difference among large cardamom accessions.
\end{abstract}

Copy Right.IJAR.2016. Allnightsreserved.

\section{Introduction:-}

The genus Amomum is the second largest genus of the family Zingiberaceae with c. 150 species (Thomas et al., 2009). This species is indigenous to moist deciduous and semi-evergreen forests of sub-Himalayan tracts at an altitude ranging from 500- $2000 \mathrm{~m}$. (Sharma, 2009). Nepal is top most producer of large cardamom in the world (Shrestha et al., 2008). The annual production is $6026 \mathrm{Mt}$ from areas of 11665 hectares (MOAD, 2012). Large Cardamom is mostly grown in Nepal, India and Bhutan. Regeneration through seed is difficult in large cardamom due to dormancy of seed (Bisht et al., 2010) hence; clonal propagation is widely adopted among farmers. Large cardamom has high value because of its medicinal properties such as for stomachic, carminative and stimulant (Singh, 1982) and has high demand in world market. Its cultivation has drastically increased in Nepal due to its high economic impact and also social and environmental advantages (Niroula, 1998).

Random Amplified Polymorphic DNA markers are widely employed in genetic research due to its simplicity and speed (Williams et al., 1990; Welsh and McClelland, 1990). RAPD are effective in producing species specific fingerprints therefore used in several crops for identification, characterization and estimation of genetic relatedness (Ganesh Ram et al., 2008 and Yeotkar et al., 2011) so these markers also can be used for assessment of genetic variation that are important key tools for crop improvement and germplasms conservation (KalyanBabu et al., 2007). Molecular markers which detect variation at the DNA level overcome most of the limitations of morphological and biochemical markers hence potential application of RAPD markers has been demonstrated in many crops since long time (Bowditch et al., 1993 and Zhang et al., 2011). Due to polymorphism shown by these markers it is quite useful for genetic diversity analysis in most of the crops (Pandiyan, 2010, Bardakci, 2001). The 
aim of this study was to compare RAPD profiles of sixteen large cardamom cultivars and to estimate phylogenetic relationships between the investigated cultivars on the basis of the obtained RAPD profiles. Large cardamom nomenclature is interesting in Nepal as the farmer named large cardamom cultivars according to the adaptability of individual accessions to their climatic situation so researcher are confused on the diversity situation of large cardamom so this paper also aimed to differentiate the large cardamom accessions popular in different geographical regions of Eastern part of Nepal.

\section{Materials and methods:-}

The sixteen plant material (Amomum subulatum) used in this study were collected from Taplejung, Panchthar and Ilamdistrictsof Eastern Nepal (Figure 1) during 2012. Immature leaf samples were collected from various ecogeographical locations of different altitude irrespective of wild as well as cultivated genotype. The samples were transported to the laboratory as soon as possible and stored at $-40^{\circ} \mathrm{C}$ until DNA extractions. Geographical situations of collected samples were recorded with the help of GPS machine (GPS Garmin).Each sample were reduced to fine powder through mortar and pestle with addition of liquid $\mathrm{N}_{2}$ and transferred to a $2.0 \mathrm{ml}$ eppendorf tube. DNA extraction was performed using a modified CTAB method (Doyle and Doyle, 1990), where modification was done for $\mathrm{CTAB}$ buffer reaction time at $65^{\circ} \mathrm{C}$ for 1 hour. DNA concentration was estimated by Q5000 UV visSpectrophotometer(Quawell).

RAPD amplification was performed with random decamers(Kit from Operon Technologies, Alameda, CA, USA). On preliminary experimentation sixty primers were tested but only twenty five arbitrary RAPD primers (Table 1) showed reproducible banding pattern and were chosen for the analysis based on highly readable and polymorphic bands as described by Pandiyan et al., 2010.

DNA amplifications were performed in $15 \mu \mathrm{l}$ reaction volume containing 50ng template DNA, 2X Green GoTaq ${ }^{\circledR}$ Reaction Buffer (pH 8.5), $400 \mu \mathrm{M}$ dATP, $400 \mu \mathrm{M}$ dGTP, $400 \mu \mathrm{M}$ dCTP, $400 \mu \mathrm{M}$ dTTP and $3 \mathrm{mM} \mathrm{MgCl} 2$. (Promega) and 0.6picomole of primer. The mixture was gently mixed and centrifuged in shaker for 60 seconds prior to adding two drops of mineral oil. After addition of mineral oil it was transformed to thermocycler, All the amplifications were performed in the same thermocycler (MULTIGENE OPTIMAX, LabnetInternational, Inc.) programmed for 1 cycle of $95^{\circ} \mathrm{C}$ for $5 \mathrm{~min}$ followed by 40 cycles of $95^{\circ} \mathrm{C}$ for $60 \mathrm{sec}, 36^{\circ} \mathrm{C}$ for $1 \mathrm{~min} 30 \mathrm{sec}, 72^{\circ} \mathrm{C}$ for $2 \mathrm{~min}$, and final 1 cycle of $72^{\circ} \mathrm{C}$ for $10 \mathrm{~min}$. Samples were kept at $2^{\circ} \mathrm{C}$ until further analysis. $12 \mu \mathrm{l}$ aliquots of amplification products were loaded in a $1 \%(\mathrm{w} / \mathrm{v})$ agarose gel (Bioneer) for PCR product separation in 1X TAE buffer (Bioneer) in an electrical field $(120 \mathrm{~V})$ for 90 minutes. Gels was stained with Ethidium Bromide $(0.5 \mu \mathrm{g} / \mathrm{ml}$ for $30 \mathrm{~min})$ and visualized under exposure of UV light under gel doc system (UVDI, Major Science). For scoring band and to confirm consistent amplifications during the whole experiment standard $1 \mathrm{~kb}$ Ladder (Bioneer) was used.

RAPD profiles of 16 different cultivars (Figure 1) were scored on binary system as 1 for presence of band and 0 for absence of band. Only the bands that are clear and reproducible were scored. Polymorphic Information Content (PIC) for each primer were calculated as described by Roldan Ruiz et al., (2000) as PIC=2Pi (1-Pi), Where Pi is the frequency of $\mathrm{i}^{\text {th }}$ null allele. Scored bands were subjected to study the Dice similarity coefficient with the help of NTSYS pc version 2.01 and based on genetic distance UPGMA genetic map were created. To confirm the clustering pattern further principle coordinate analysis was performed. GeneAlex 6.1 was used to estimate Nei's genetic diversity and Shannon's Information Index. 


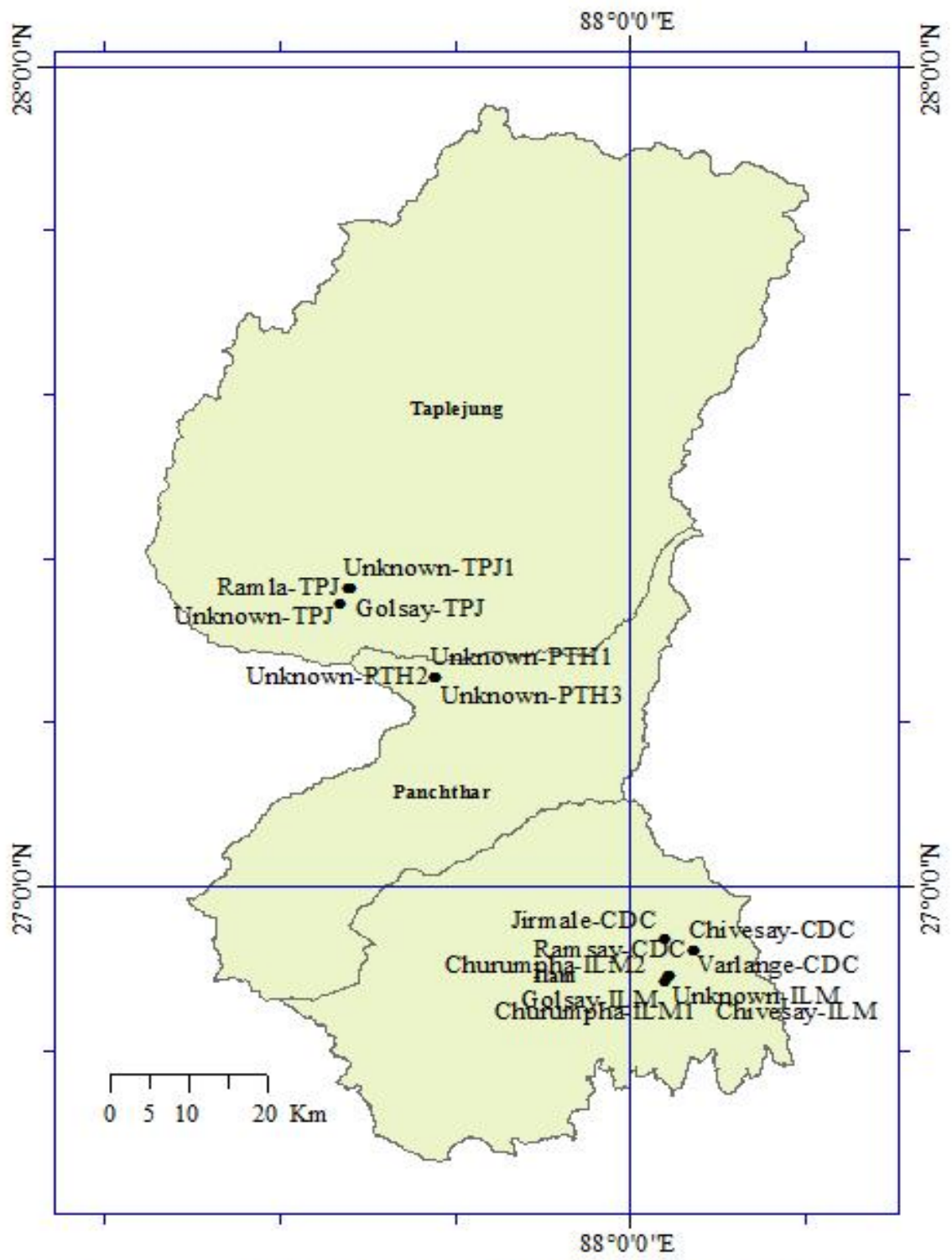

Figure 1: Large cardam om sample collection places in Mechi zone of Nepal

\section{Results and discussion:-}

A total of 169 loci were generated by 25 random decamersfor overall 16 cultivars with average of 6.76 loci per primers. Nine different primers produce 7 locieachhowever, the polymorphic information content varies among primers suggest that there is high level of gene diversity among collected accessions.Minimum number of loci generated is 4 by primer OPB- 11 and maximum of 10 by primers OPA-03, OPB-01 and OPB-02. Polymorphic information content varies from 0.15 by primer OPAH- 09 to 0.47 by OPB-16 with average of $0.34 \pm 0.15$.

Highest genetic distance (0.694) was found between Ramla cultivar of Taplejung district with Churumpha cultivar collected fromIlam district. Similarly, lowest genetic distance $(0.111)$ is found between Chivesay cultivar of Ilam district with unidentified cultivars of Panchthar district.

Nei'sheterozygosity for all the loci ranges from 0 to 0.5 with mean $0.295 \pm 0.013$, similarly unbiased heterozygosity was $0.304 \pm 0.013$. Shannon's information index was found to be 0.448 . 
This suggests broad genetic base for selected cultivars of large cardamom. Selection of wild relatives of large cardamom in this study is major reason for broad genetic base among collected large cardamom accessions. The present molecular diversity study revealed a high genetic variability as reported earlier in zingibers by Jaleel and Sasikumar, 2010.

For phylogentic study UPGMA clustering was performed as it is simplest method for constructing tree or phenogram. UPGMA assumes a constant rate of evolution and it was originally used to represent the extent of phenotypic similarity for a group of species in numerical taxonomy. Four different clusters (Figure 2) were formed afterDice similarity coefficientat 0.68 ; wild relative of large cardamom (Churumpha) formed separate cluster with other two cultivars from Ilam district. Varlange cultivar collected from Cardamom Development Center, Ilam was found in another separate cluster and is entirely different from other accessions, This may be due to abundance of this cultivars only in high altitude with greenish color of the stem as well as inflorescence. This cultivar produce relatively large size capsule than other cultivars (Thomas et al., 2009). Chivesay cultivars collected from Ilam district along with other three unidentified cultivars form separate cluster, this type of cultivars are different from other in terms of capsule size (relatively small). Though Golsay cultivars form separate cluster it is closely related with Ramla, Ramsay and Jirmale cultivar; production of confectionery type of capsule are best described to these cultivars.

Principle coordinate analysis (PCoA) is realistic in representation of cultivars based on mean values. PCoA analysis was found informative in deciding nature of cluster and the variances shown by the respective coordinates are highly used in agricultural researches (Maji and Shaibu, 2012). The cluster pattern generated through UPGMA clustering is well supported by the principle coordinate analysis that also separates all cultivars into four major groups (Figure 3). Upon PCoA analysis variation in $\mathrm{X}$ axis was found $35.87 \%$ in $\mathrm{Y}$ axis $23.51 \%$ and in $\mathrm{Z}$ axis it is $13.69 \%$ (Figure 3). These cluster patterns showed that wild relatives of large cardamom were distinct form cultivated cultivars and there was high genetic dissimilarity between wild genotypes to the locally cultivated genotypes. Use of RAPD marker in such genetic variability analysis was previously described by Belaj et al., 2003, Mignouna et al., 1998, Raghunathachari et al., 2000 and Salazar et al., 2006 in different crops and plants. Gupta et al. (2006) described the variation in large cardamom based on certain morphological traits. Similarly, our results based on molecular analysis also reveal the highly diverse nature of large cardamom exist in nature. Cross pollination nature (Sinu and Shivanna, 2007) of this crop may also be the reason for forcing this crop as heterogeneous in nature. 
Table 1:-List of primers, sequence, number of band amplified, range of amplified bands and polymorphic information content.

\begin{tabular}{|c|c|c|c|c|c|}
\hline S.N. & Primer code & $\begin{array}{l}\text { Primer sequences } \\
\left(5^{\prime} \text { to } 3^{\prime}\right)\end{array}$ & $\begin{array}{c}\text { Number of band } \\
\text { amplified }\end{array}$ & $\begin{array}{l}\text { Approx. Range of } \\
\text { amplified bands } \\
(\mathrm{kb})\end{array}$ & $\begin{array}{c}\text { Polymorphic } \\
\text { Information } \\
\text { Content }\end{array}$ \\
\hline 1 & OPA-03 & AGTCAGCCAC & 10 & $0.3-1.8$ & $0.38 \pm 0.06$ \\
\hline 2 & OPA-10 & GTGATCGCAG & 7 & $0.3-1.6$ & $0.36 \pm 0.18$ \\
\hline 3 & OPA-11 & CAATCGCCGT & 7 & $0.6-1.6$ & $0.33 \pm 0.20$ \\
\hline 4 & OPA-13 & CAGCACCCAC & 8 & $0.5-1.5$ & $0.31 \pm 0.15$ \\
\hline 5 & OPA-17 & GACCGCTTGT & 6 & $0.3-1.6$ & $0.34 \pm 0.14$ \\
\hline 6 & OPA-18 & AGGTGACCGT & 5 & $0.3-1.5$ & $0.37 \pm 0.10$ \\
\hline 7 & OPA-19 & CAAACGTCGG & 6 & $0.3-2.2$ & $0.33 \pm 0.08$ \\
\hline 8 & OPAH-05 & TTGCAGGCAG & 8 & $0.4-1.5$ & $0.38 \pm 0.18$ \\
\hline 9 & OPAH-08 & TTCCCGTGCC & 7 & $0.4-1.5$ & $0.32 \pm 0.23$ \\
\hline 10 & OPAH-09 & AGAACCGAGG & 7 & $0.8-1.6$ & $0.15 \pm 0.17$ \\
\hline 11 & OPV-19 & GGGTGTGCAG & 6 & $0.7-1.25$ & $0.25 \pm 0.19$ \\
\hline 12 & OPT-01 & GGGCCACTCA & 7 & $0.5-1.5$ & $0.35 \pm 0.13$ \\
\hline 13 & OPT-07 & GGCAGGCTGT & 7 & $0.5-1.61$ & $0.37 \pm 0.12$ \\
\hline 14 & OPB-01 & GTTTCGCTCC & 10 & $0.4-2.0$ & $0.38 \pm 0.13$ \\
\hline 15 & OPB-02 & TGATCCCTGG & 10 & $0.2-2.1$ & $0.39 \pm 0.12$ \\
\hline 16 & OPB-09 & TGGGGGACTC & 4 & $0.3-1.0$ & $0.36 \pm 0.16$ \\
\hline 17 & OPB-10 & CTGCTGGGAC & 7 & $0.3-2.0$ & $0.29 \pm 0.21$ \\
\hline 18 & OPB-11 & GTAGACCCGT & 4 & $0.3-1.8$ & $0.22 \pm 0.16$ \\
\hline 19 & OPB-12 & CCTTGACGCA & 9 & $0.2-2.2$ & $0.39 \pm 0.10$ \\
\hline 20 & OPB-13 & TTCCCCCGCT & 7 & $0.3-2.9$ & $0.38 \pm 0.18$ \\
\hline 21 & OPB-14 & TCCGCTCTGG & 7 & $0.2-1.6$ & $0.36 \pm 0.13$ \\
\hline 22 & OPB-15 & GGAGGGTGTT & 5 & $0.4-1.6$ & $0.38 \pm 0.15$ \\
\hline 23 & OPB-16 & TTTGCCCGGA & 5 & $0.2-1.2$ & $0.47 \pm 0.05$ \\
\hline 24 & OPB-18 & CCACAGCAGT & 5 & $0.3-2.0$ & $0.25 \pm 0.16$ \\
\hline 25 & OPB-19 & ACCCCCGAAG & 5 & $0.2-2.2$ & $0.35 \pm 0.15$ \\
\hline \multicolumn{3}{|c|}{ Mean } & $6.76(169)$ & & $0.34 \pm 0.15$ \\
\hline
\end{tabular}

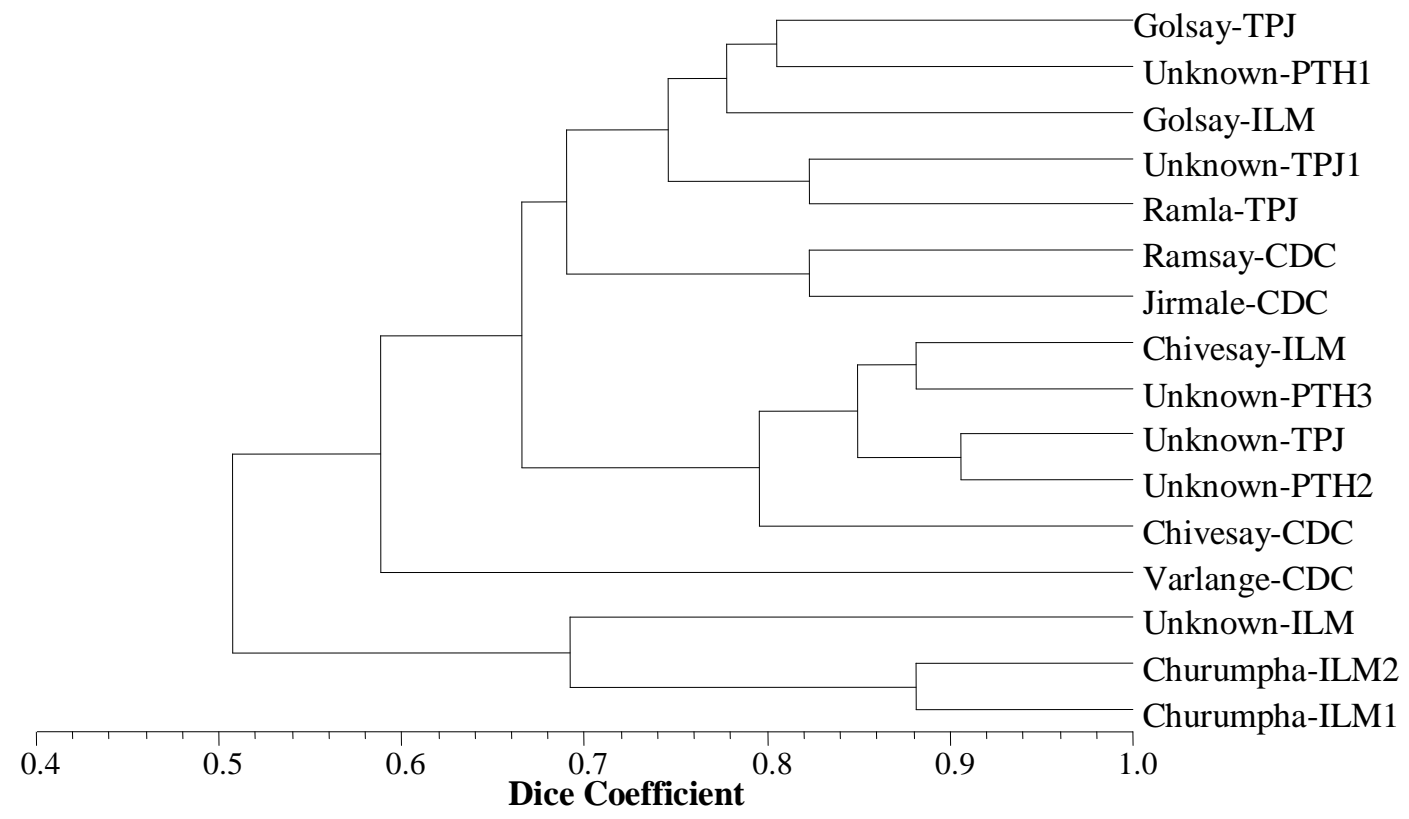

Figure 2:- UPGMA clustering of 16 accessions based on 169 loci generated by 25 random primers. 


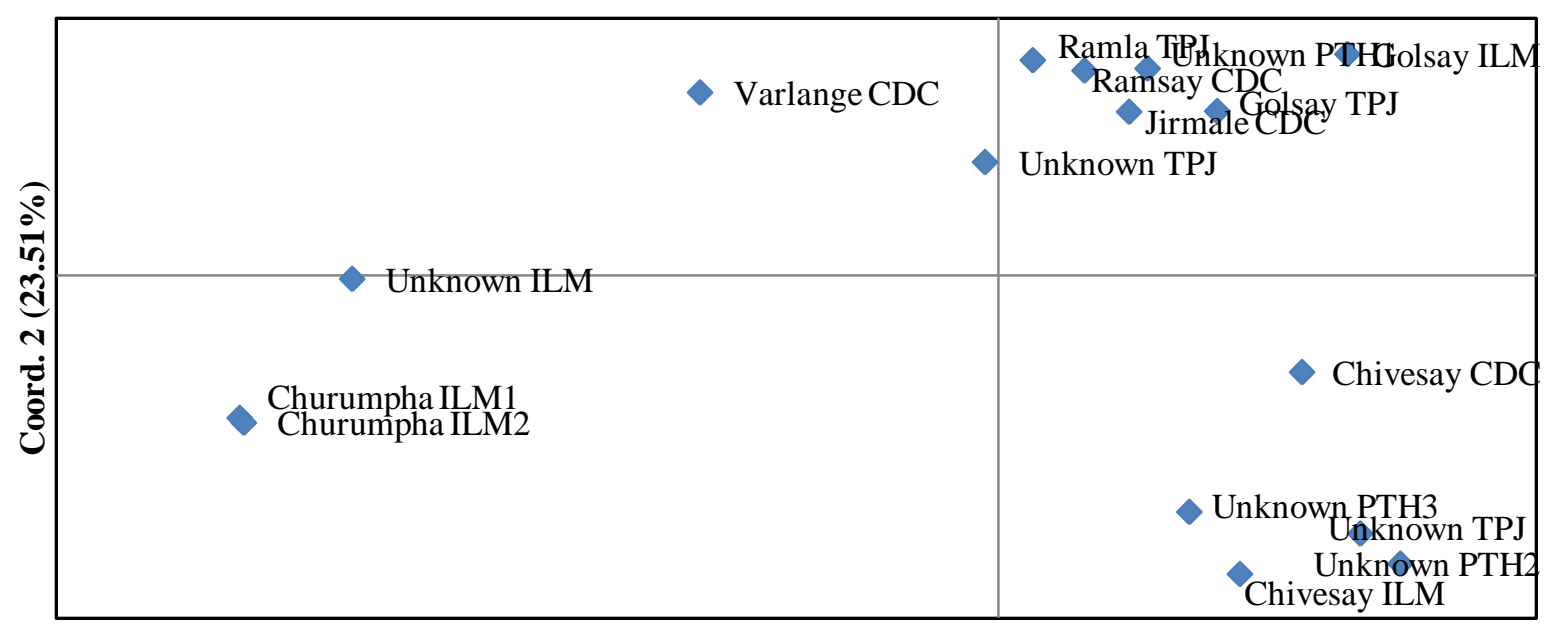

Coord. $1(35.87 \%)$

Figure 3:-Principle coordinate analysis of 16 large cardamom cultivars. 
Table 2:-Genetic distances among 16 large cardamom accessions based on 169 loci generated by 25 random primers.

\begin{tabular}{|c|c|c|c|c|c|c|c|c|c|c|c|c|c|c|c|c|}
\hline & 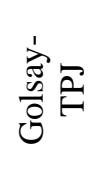 & 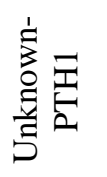 & 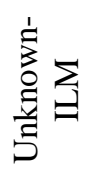 & 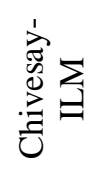 & 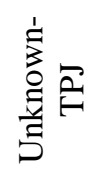 & 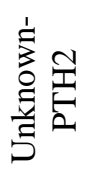 & 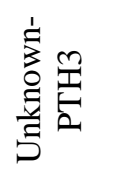 & 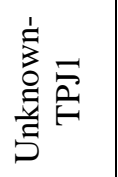 & 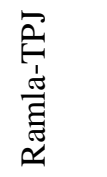 & 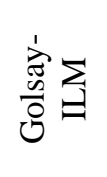 & 胥 & 总 & 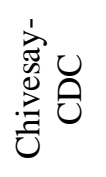 & 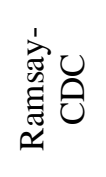 & 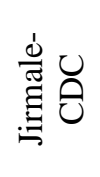 & 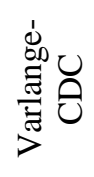 \\
\hline Golsay-TPJ & 0.000 & & & & & & & & & & & & & & & \\
\hline Unknown-PTH1 & 0.221 & 0.000 & & & & & & & & & & & & & & \\
\hline Unknown-ILM & 0.592 & 0.591 & 0.000 & & & & & & & & & & & & & \\
\hline Chivesay-ILM & 0.325 & 0.381 & 0.568 & 0.000 & & & & & & & & & & & & \\
\hline Unknown-TPJ & 0.273 & 0.333 & 0.549 & 0.143 & 0.000 & & & & & & & & & & & \\
\hline Unknown-PTH2 & 0.299 & 0.349 & 0.580 & 0.111 & 0.082 & 0.000 & & & & & & & & & & \\
\hline Unknown-PTH3 & 0.329 & 0.429 & 0.571 & 0.127 & 0.184 & 0.140 & 0.000 & & & & & & & & & \\
\hline Unknown-TPJ1 & 0.333 & 0.455 & 0.649 & 0.424 & 0.419 & 0.438 & 0.371 & 0.000 & & & & & & & & \\
\hline Ramla-TPJ & 0.306 & 0.294 & 0.625 & 0.477 & 0.425 & 0.444 & 0.443 & 0.313 & 0.000 & & & & & & & \\
\hline Golsay-ILM & 0.230 & 0.244 & 0.664 & 0.353 & 0.301 & 0.304 & 0.396 & 0.353 & 0.313 & 0.000 & & & & & & \\
\hline Churumpha-ILM1 & 0.542 & 0.581 & 0.362 & 0.497 & 0.497 & 0.538 & 0.523 & 0.616 & 0.675 & 0.638 & 0.000 & & & & & \\
\hline Churumpha-ILM2 & 0.603 & 0.632 & 0.411 & 0.524 & 0.546 & 0.565 & 0.525 & 0.628 & 0.694 & 0.689 & 0.143 & 0.000 & & & & \\
\hline Chivesay-CDC & 0.224 & 0.333 & 0.506 & 0.205 & 0.156 & 0.179 & 0.226 & 0.380 & 0.400 & 0.288 & 0.515 & 0.580 & 0.000 & & & \\
\hline Ramsay-CDC & 0.233 & 0.325 & 0.537 & 0.406 & 0.348 & 0.341 & 0.350 & 0.466 & 0.395 & 0.289 & 0.519 & 0.562 & 0.269 & 0.000 & & \\
\hline Jirmale-CDC & 0.278 & 0.341 & 0.516 & 0.371 & 0.298 & 0.323 & 0.341 & 0.461 & 0.453 & 0.261 & 0.512 & 0.577 & 0.265 & 0.172 & 0.000 & \\
\hline Varlange-CDC & 0.441 & 0.493 & 0.466 & 0.503 & 0.515 & 0.534 & 0.475 & 0.513 & 0.540 & 0.520 & 0.535 & 0.585 & 0.459 & 0.392 & 0.380 & 0.000 \\
\hline
\end{tabular}




\section{Conclusion:-}

This study demonstrates that genetic base for collected large cardamom is very high and there is potentialityof RAPD markers in differentiating cultivars distributed in Eastern hills of Nepal. The feasibility of the RAPD marker technique for quantifying genetic distance among large cardamom accessions is found useful and additional use of markers will help to verify the pattern of variation of large cardamom exist in nature.

\section{References:-}

1. Anderson, J.A., G.A. Churchill, J.E. Autrique, S.D. Tanksley, and M.E. Sorrells. 1993. Optimizing parental selection for genetic linkage maps. Genome 36:181-186.

2. Bardakci, F.2001. Random Amplified Polymorphic DNA (RAPD) markers.Turk. J. Biol. 25: 185-196

3. Belaj A, Z. Satovic and G. Cipriani. 2003. Comparative study of the discriminating capacity of RAPD, AFLP and SSR markers and of their effectiveness in establishing genetic relationships in olive. Theoretical and Applied Genetics.107: 736-744.

4. Bisht, V. K., V. Purohit, J. S. Negi and A. K. Bhandari. 2010. Introduction and Advancement in Cultivation of Large Cardamom (Amomum subulatum Roxb.) in Uttarakhand, India. Research Journal of Agricultural Sciences. 1(3): 205-208

5. Bowditch, B.M., D.G. Albright, J.G.K.Williams, and M.J. Braun. 1993. Use of randomly amplified polymorphic DNA markers in comparative genome studies. Methods Enzymol. 224: 294-309.

6. Doyle,J.J. and J.L.Doyle.1990. Isolation of plant DNA from fresh tissue. Focus 12:13-15

7. Ganesh Ram, S., K. T. Parthiban, R. Senthil Kumar, V. Thiruvengadam and M. Paramathma. 2008. Genetic diversity among Jatropha species as revealed by RAPD markers. Genet Resour Crop Evol. 55:803-809

8. Gupta, U., K.M. Kuruvilla, P.P. Menon, K.J. Madhusoodanan and J. Thomas.2006.Multivariate analysis in large cardamom(Amomum subulatum Roxb.).Journal of spices and aromatic crops. 15 (2): 133-135

9. Harisaranraj, R., K. Suresh and S. Saravanababu. 2009. DNA Finger Printing Analysis among Eight Varieties of ZingiberofficinaleRosc. By Using RAPD Markers. Global Journal of Molecular Sciences. 4 (2): 103-107

10. Jaleel, K. and B. Sasikumar. 2010. Genetic diversity analysis of ginger (ZingiberofficinaleRosc.)germplasms based in RAPD and ISSR markers.Scientia Hort.125: 73-76

11. Kalyana-Babu, B., N.Senthil, S.Michael-Gomez, K. R. Biji, and N. S. Rajendraprasad.2007. Assessment of genetic diversity among finger millet (Eleusinecoracana (L.)Gaertn.)accessions using molecular markers. Genet.Resour. Crop Evol. 54:399-404.

12. Maji, A. T. and A. A. Shaibu. 2012. Application of principal component analysis for rice germplasm characterization and evaluation. Journal of Plant Breeding and Crop Science. 4(6), pp. 87-93

13. MOAD. 2012. Statistical Year Book. Ministry of Agriculture Development, Singhdarbar, Kathmandu, Nepal

14. Mignouna, H.D., N.Q. Ng, J. Ikca and G. Thottapilly. 1998. Genetic diversity in cowpea as revealed by random amplified polymorphic DNA. J. Genet. Breed. 52: 151 - 159.

15. Niroula, G.S. 1998. Spices-potential crops for export market.Proceedings of the National Horticulture Workshop. Nepal Horticulture Society, Kathmandu.

16. Pandiyan, M., N. Senthil, P. Sivakumar, A. R. Muthiah and N. Ramamoorthi. 2010. Genetic Diversity Analysis among Greengram genotypes using RAPD Markers. Electronic Journal of Plant Breeding. 1(4): 466-473

17. Peakall, R. and P.E. Smouse. 2012. GenAlEx 6.5: genetic analysis in Excel. Population genetic software for teaching and research-an update. Bioinformatics In press.

18. Raghunathachari, P., V. K. Khanna, U. S. Singh and N. K. Singh. 2000. RAPD analysis of genetic variability in Indian scented rice germplasm (Oryza sativa L.). Current Science. 79:994-998

19. Roldan-Ruiz, I., J. Dendauw, E. VanBockstaele, A. Depicker\& M. De Loose. 2000. AFLP markers reveal high polymorphic rates in ryegrasses (Lollium spp.). Mol. Breed. 6:125-134

20. Salazar, B., H. Laurentin, M. Davila and M.A. Castillo. 2006. Reliability of the RAPD technique for germplasm analysis of sesame (Sesamumindicum L) from Venezuela. Interciencia. 31:456-460

21. Sharma, G., R. Sharma and E. Sharma. 2009. Traditional knowledge system in Large Cardamom farming: biophysical and management diversity in Indian mountainous regions. Indian Journal of Traditional Knowledge. $8(1): 17-22$

22. Shrestha, K.P., P.L. Karn and C.B. Shrestha. 2001. A study report on Large Cardamom, Marketing in Nepal and India. Nepal Agriculture Research Council, Agriculture Research Station, Pakhribas, Dhankuta

23. Singh, K.A., R.N. RaiPatiram and D.T. Bhutia. 1982. Large Cardamom (Amomum subulatum Roxb) plantationAn age old agroforestry system in Eastern Himalaya. ICAR Research complex for NEH Region, Sikkim CentreTadog, 737102, Gonggtok, India 
24. Sinu, P.A., and K.R. Shivanna. 2007. Pollination biology of large cardamom (Amomum subulatum).Current Science. 93 (4): 548-552

25. Thomas, V.P., M. Sabu and U. Gupta. 2009. Taxonomic studies on cultivars of Amomum subulatum (Zingiberaceae). Rheedea. 19:25-36

26. Welsh, J. and M. Mcclelland.1990. Fingerprinting genomes using PCR with arbitrary primers. Nucleic Acids Res. 18:7213-7218

27. Williams, J. G. K., A. R. Kubelic, R. J. Livak and S. V.Tingey. 1990. DNA polymorphisms amplified by arbitrary primers are useful as genetic markers. Nucleic Acids Res. 18:6531-6535

28. Yeotkar Swati, D., S.N. Malode, V.N. Waghmare and P. Thakre. 2011. Genetic relationship and diversity analysis of Clitoriaternatea variants and Clitoriabiflora using random amplified polymorphic DNA (RAPD) markers. African Journal of Biotechnology. 10(79):18065-1807

29. Zhang, X.Y., R.R.C Wang and Y.S. Dong. 1996. RAPD polymorphism in Aegilosgeniculata Roth CAC.O Vataacut. Non. L.) Genet. Res. Crop Evol. 43: 429 - 433. 